\title{
Effect of Machine Setting Parameters on Ring Slub Carded Yarn Quality and Spinning Performance
}

\author{
Md. Din Islam, Md. Rokonuzzaman, Joykrisna Saha*, Abdur Razzaque \\ Department of Textile Engineering, Mawlana Bhashani Science and Technology University, Santosh, Tangail, Bangladesh

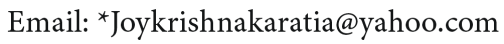

How to cite this paper: Islam, Md.D., Rokonuzzaman, Md., Saha, J. and Razzaque, A. (2017) Effect of Machine Setting Parameters on Ring Slub Carded Yarn Quality and Spinning Performance. Journal of Textile Science and Technology, 3, 45-55.

https://doi.org/10.4236/jtst.2017.34004

Received: October 7, 2017

Accepted: November 27, 2017

Published: November 30, 2017

Copyright $\odot 2017$ by authors and Scientific Research Publishing Inc. This work is licensed under the Creative Commons Attribution International License (CC BY 4.0).

http://creativecommons.org/licenses/by/4.0/ Open Access

\begin{abstract}
At present ring slub carded yarn is very popular to produce value added product for ornamentation purpose in the apparel industry. During spinning different parameters influenced the spinning performance. The main aim of this study was to investigate the effect of spindle speed as well as traveller weight on yarn quality. The $\mathrm{Ne} 28, \mathrm{Ne} 30$ and $\mathrm{Ne} 34$ carded slub yarns were produced at the spindle speed of $15,500 \mathrm{rpm}, 16,000 \mathrm{rpm}, 16,500 \mathrm{rpm}, 17,000$ $\mathrm{rpm}$ and $17,500 \mathrm{rpm}$ on the ring frame with using traveller number $3 / 0,4 / 0$, $5 / 0$ and $6 / 0$. The yarn properties like mass variation percentage (CVm\%), unevenness (U\%), hairiness, yarn breakage rate, yarn imperfection were investigated. It was found that traveller number $5 / 0$ showed lower $\mathrm{Um} \%, \mathrm{CVm} \%$ for Ne 28 and Ne 30 carded slub yarn compared to traveller number 3/0 and 4/0. On the other hand traveller number $6 / 0$ showed better $\mathrm{Um} \%, \mathrm{CVm} \%$, thin places $(-50 \%) / \mathrm{km}$ and end breakage $\%$ for Ne 34 carded slub yarn compared to traveller number $4 / 0$ and 5/0. It was also observed that increasing end breakage rate as the spindle speed of ring frame was increased.
\end{abstract}

\section{Keywords}

Slub Yarn, End Breakage, Spindle Speed, Traveller

\section{Introduction}

The fancy yarn like slub carded yarn which creates special appearance in the outside of fabric is widely used for decorative purpose in apparels industry. This special appearance depends on different parameters of slub yarn which are slub length, slub thickness, slub/meter, slub distance. Approximately 100,000 tons fancy yarns are produced per year all over the world [1]. At present slub yarns 
are becoming more popular than conventional yarns in denim factory [2]. Among the fancy yarns, slub yarn creates good position in textile sector for producing value added product [3]. At present, slub yarn is used in versatile application like denim, shirting, knitwear, casual wear and ladies dress material. These depend on different thickness and length of slub, giving a wide range of effects [4].

The fancy yarn consists of two parts: the slubs (or flames) and the spacings (Figure 1).

This novelty generates a change in yarn properties compared to the conventional yarn. The slub yarn studied is produced on the ring spinning system equipped with the Amsler device [5].

In ring spinning system traveller is the most essential component for spun yarn production. Different weights of travellers are used in ring spining. Traveller weight controls the degree of frictional forces between the traveller and the ring which influences the winding speed and balloon tension [6]. Weight of the traveller to be selected depends upon the yarn count, yarn strength, spindle speed and raw material. Traveller weight influences yarn quality and production. Experience has shown that, for any given traveller, there is a limit to maximum practical speed; if that is exceeded, the high amount of heat develops due to the friction with the ring. In turn, the traveller is burnt, in a very short time, and fly of the rings. When this happens in a spinning room, the "ends down" or breakage rate is increased. Yarn quality parameters can be improved by proper traveller weight selection, which results in reducing yarn breakages, mass variation, twist variation and hairiness. In this way, the increased quantity and quality of the yarn along with the low spinning cost can be obtained [7].

Normally light weight and heavier weight travellers are used for the production of fine yarn and coarser yarn spinning correspondingly. In addition, travellers life is very short, so travellers are replaced frequently to minimize the unnecessary machine stoppage [8] [9]. In staple yarn manufacture, ring spinning system is still now dominating the spun yarn production area amongst all the spinning systems because of special characteristics of these yarns which supply excellent apparel fabric properties [10]. Rotor, friction and air jet systems are unconventional spinning techniques which produce yarns at a much faster rate than the ring spinning system. But these yarns are not equal with ring yarns in terms of strength, especially as an end product of fabric for apparels [11] [12]. The productivity of ring frame mostly depending on a higher spindle speed has become necessary for higher productivity [13]. High spindle speeds generate

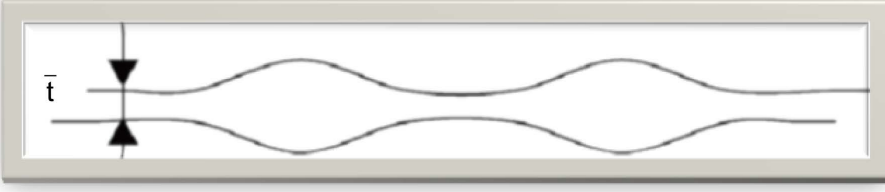

Figure 1. Slub yarn configuration. 
problems during spinning such as high yarn breakage rate, hairiness, strength loss and fly generation [14] [15]. The aim in this study is to produce yarn at high speed by using suitable traveler and maintaining yarn quality.

A variety of methods are available for producing slub yarns, like ring-spun slub yarns and rotor-spun slub yarns. In these methods, ring spinning is the earliest and also the most common processing technology in slub yarn production at the present time. A well-known method in this process is to modify the ring spinning frame in such a way that the intermittent acceleration of the drafting rollers produces constant varying degrees of draft to be applied [16]. In this research four different weights of travellers were selected and their influence on the production and quality of $28 / 1,30 / 1$ and $34 / 1$ cotton carded slub yarn were determined at different spindle speed of 15,500,16,000,16,500,17,000, 17,500 rpm. Mass variation percentage (CVm \%), Unevenness (U \%), Yarn hairiness, End breakage rate, Thick places and thin places were determined as the quality parameters.

\section{Materials \& Methods}

\subsection{Materials Properties Which Are Used in Experiment}

Through this study it has been selected CIS (Uzbekistan) cotton fibers. Properties of cotton fibers are shown below-

$28 / 1,30 / 1$, and $34 \mathrm{Ne}$ carded slub yarn samples were produced from the above mention raw cotton sample.

\subsection{Methods}

At first selected cotton is to be tested by USTER ${ }^{\circledR}$ HVI 1000 and the result of is shown in Table 1 . And process materials properties have been tested by process controlled machine of USTER ${ }^{\circledR}$ AFIS PRO and the result is shown in Table 2. In

Table 1. HVI and AFIS report.

\begin{tabular}{cccc}
\hline \multicolumn{1}{c}{ HVI Report } & \multicolumn{2}{c}{ AFIS Report } \\
\hline Parameter & Value & Parameter & Value \\
\hline SCI & 147 & UQL (W) mm & 200 \\
MIC & 4.75 & Neps (Cnt/gm) & 15 \\
Length (mm) & 28.63 & SCN (Cnt/gm) & 4.40 \\
Uniformity & 83.6 & SFC (w) & 14.40 \\
SFI & 8.5 & SFC (n) & 5.40 \\
GPT & 33.5 & IFC \% & 168 \\
Elongation (\%) & 5.60 & Fineness (mtex) & 0.92 \\
Moisture (\%) & 6.60 & Maturity Ratio & \\
Color Grade & $11-4$ & & \\
Trash Grade & 2.4 & & \\
\hline
\end{tabular}


Table 2. Instruments that are used in analysis.

\begin{tabular}{cc}
\hline M/C Name & Manufacturer \\
\hline Yarn strength tester & Mesdan, Italy \\
USTER auto sorter & Switzerland \\
Digital twist tester & Mesdan, Italy \\
Tachometer & England \\
Hand held moister meter & England \\
Auto yarn winder & Mesdan, Italy \\
Digital balance & USA \\
Electronic Wrap Reel & Mesdan, Italy \\
USTER ${ }^{\circledR}$ AFIS PRO & USA \\
USTER HVI 1000 $^{\circledR}$ & Switzerland \\
USTER ${ }^{\circledR}$ TESTER-5 & Switzerland \\
Electronic Wrap Reel (for Sliver \& Roving) & Mesdan, Italy \\
Moisture Meter & Germany \\
\hline
\end{tabular}

back process, all stage like carding, breaker drawing, finisher drawing \& simplex process materials are to be tested by wrap block. First sample of $28 / 1,30 / 1$, and $34 / 1 \mathrm{Ne}$ carded slub yarn is made from ring frame where slub attachment was mounted. Then ring cops of slub yarns are tested by Uster- 5 and the result of slub yarns are analyzed and U\%, CVm\%, Thin (-50\%), Thick (+50\%), Hairiness, end breakage\% slub yarn slub length, slub thickness, slub/meter and pause length measured by Uster- 5 and manually measure by scale \& balance.

\section{Results and Discussion}

\subsection{Effect of Ring Spindle Speed and Traveller Number on Yarn Evenness}

Yarn evenness can be expressed by two ways: 1) The irregularity U\%; 2) The coefficient of mass variation $\mathrm{CVm} \%$.

From Table 3 it was observed that when spindle speed increases gradually increases yarn unevenness and co-efficient of mass variation. Light weight traveller is responsible for increasing yarn unevenness and co-efficient of mass variation and vice versa. The yarn unevenness and Co-efficient of mass variation percentage of Ne 28 was lower than Ne 30 carded slub yarn in all cases. Fabric appearance depends on $\mathrm{CVm} \%$ and $\mathrm{Um} \%$. Lower the $\mathrm{CVm} \%$ and $\mathrm{Um} \%$ produce better fabric appearance. Higher $\mathrm{CVm} \%$ and $\mathrm{Um} \%$ value create dul fabric appearance. In case of yarn count $\mathrm{Ne} 28$, the $\mathrm{CVm} \%$ was shown 32.05, 31.81and 31.11 with the traveller number of $3 / 0,4 / 0$ and 5/0 respectively at $17500 \mathrm{rpm}$. On the other hand the yarn unevenness percentage was also shown 22.65, 22.58 and 22.04 with the traveller number of $3 / 0,4 / 0$ and $5 / 0$ respectively at $17,500 \mathrm{rpm}$ for 
Table 3. Effect of spindle speed and traveller number on yarn irregularity (U\%) and Co-efficient of mass variation (CVm\%) of Ne 28 and $\mathrm{Ne} 30$ carded slub yarn.

\begin{tabular}{|c|c|c|c|c|c|}
\hline \multicolumn{6}{|c|}{ Yarn Count Ne $28 \mathrm{Ne} 30 \mathrm{Ne} 28 \mathrm{Ne} 30$} \\
\hline Traveller Number & Spindle Speed (rpm) & $\mathrm{CVm} \%$ & $\mathrm{CVm} \%$ & $\mathrm{Um} \%$ & $\mathrm{Um} \%$ \\
\hline \multirow{5}{*}{$3 / 0$} & 15,500 & 30.90 & 31.43 & 21.33 & 22.71 \\
\hline & 16,000 & 31.33 & 31.89 & 21.66 & 22.92 \\
\hline & 16,500 & 31.65 & 32.31 & 21.77 & 23.14 \\
\hline & 17,000 & 31.94 & 32.81 & 22.54 & 23.36 \\
\hline & 17,500 & 32.05 & 32.96 & 22.65 & 23.66 \\
\hline \multirow{5}{*}{$4 / 0$} & 15,500 & 30.60 & 31.21 & 21.13 & 22.43 \\
\hline & 16,000 & 31.17 & 31.53 & 21.53 & 22.75 \\
\hline & 16,500 & 31.48 & 32.12 & 21.66 & 22.97 \\
\hline & 17,000 & 31.68 & 32.41 & 22.32 & 23.16 \\
\hline & 17,500 & 31.81 & 32.54 & 22.58 & 23.31 \\
\hline \multirow{5}{*}{$5 / 0$} & 15,500 & 30.51 & 31.17 & 21.09 & 22.19 \\
\hline & 16,000 & 30.71 & 31.35 & 21.20 & 22.42 \\
\hline & 16,500 & 30.89 & 31.95 & 21.44 & 22.71 \\
\hline & 17,000 & 30.99 & 31.99 & 21.77 & 23.06 \\
\hline & 17,500 & 31.11 & 32.13 & 22.04 & 23.15 \\
\hline
\end{tabular}

yarn count $\mathrm{Ne} 28$. In addition to the yarn count $\mathrm{Ne} 30$ also showed the similar effet. Above discussion it was clear that traveller number $5 / 0$ was given the best result as traveller number 5/0 shown lower CVm\% and Um as compared to others.

From Figure 2 \& Figure 3, it was found that when spindle speed increases and lower traveller number used ie; light weight traveller then yarn unevenness and $\mathrm{CVm} \%$ also increases and vice versa. Traveller number $4 / 0$ was shown worst result. On the other hand traveller number $5 / 0$ and $6 / 0$ were given approximately similar result. So for Ne 34 carded slub yarn traveller number $6 / 0$ is suitable. It is clear that yarn $\mathrm{U}_{\mathrm{m}} \%$ and $\mathrm{CVm} \%$ decreases with the increase in traveller mass.

The Table 4 and Figure $4 \&$ Figure 5, it was shown that number of thin places per $\mathrm{km}$ for $\mathrm{Ne} 30$ carded slub yarn was two or three times greater than $\mathrm{Ne} 28$ carded slub yarn. So it can be said that higher yarn count produces more thin places. The number of thin places of yarn count Ne 34 were 820, 436 and 422 with traveler number were $4 / 0,5 / 0$ and $6 / 0$ respectively at $17500 \mathrm{rpm}$. Whereas Ne 28 yarn count produces only 97, 77, and 77 number of thin places per kilometer at the same rpm. Traveller number $4 / 0$ was given worst vaule and traveler $6 / 0$ gives best result for $\mathrm{Ne} 34$ carded slub yarn. On the other hand there was no significance variation among the traveler number and different traveler speed for Ne 28 and Ne 30 yarn count.

In the above table and figure it was observed that when spindle speed increase 


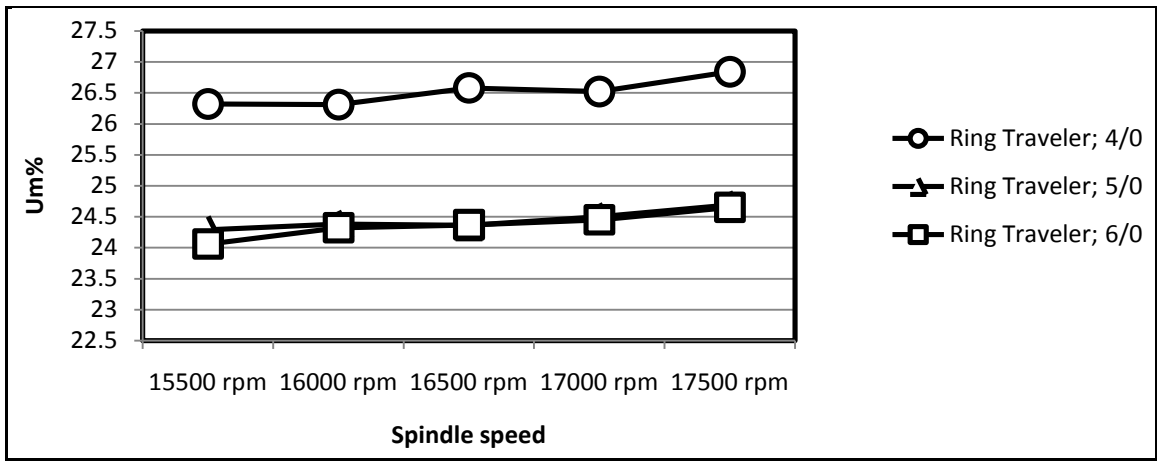

Figure 2. Um\% of Ne 34 carded slub yarn with different ring spindle speed and ring traveller.

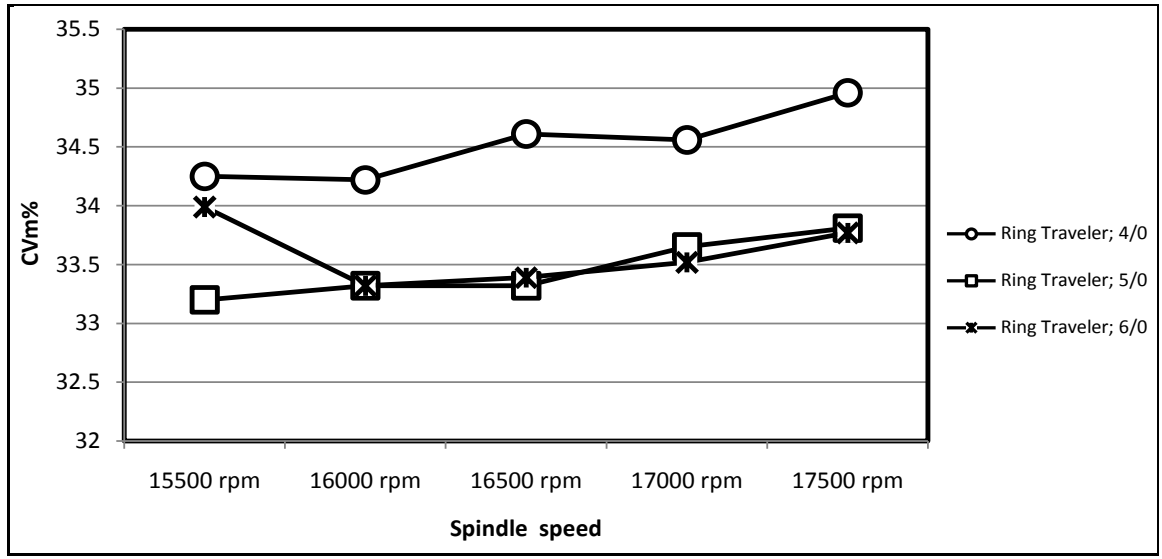

Figure 3. $\mathrm{CVm} \%$ of $\mathrm{Ne} 34$ carded slub yarn with different ring spindle speed and ring traveller.

Table 4. Effect of ring spindle speed and traveller number on yarn thin places $/ \mathrm{km}(-50 \%)$ and thick places $/ \mathrm{km}(+50 \%)$.

Yarn Count Ne 28 Ne 30 Ne 28 Ne 30

\begin{tabular}{cccccc}
\hline Traveller Number & Spindle Speed $(\mathrm{rpm})$ & Thin places $/ \mathrm{km}(-50 \%)$ & Thin places $/ \mathrm{km}(-50 \%)$ & Thick places $/ \mathrm{km}(+50 \%)$ & Thick places $/ \mathrm{km}(+50 \%)$ \\
\hline \multirow{3}{*}{$3 / 0$} & 15,500 & 52 & 158 & 2878 & 3315 \\
& 16,000 & 54 & 129 & 2850 & 3381 \\
& 16,500 & 76 & 211 & 3336 & 3397 \\
& 17,000 & 74 & 175 & 3297 & 3351 \\
$4 / 0$ & 17,500 & 97 & 166 & 2878 & 3324 \\
\hline & 15,500 & 51 & 113 & 2860 & 3339 \\
& 16,000 & 49 & 153 & 2891 & 3445 \\
& 16,500 & 72 & 170 & 2901 & 3446 \\
$5 / 0$ & 17,000 & 72 & 147 & 3058 & 3512 \\
\hline 17,500 & 59 & 160 & 2776 & 3418 \\
& 15,500 & 34 & 103 & 2780 & 3381 \\
& 16,000 & 65 & 134 & 2799 & 3386 \\
& 16,500 & 56 & 127 & 2806 & 3349 \\
\hline
\end{tabular}




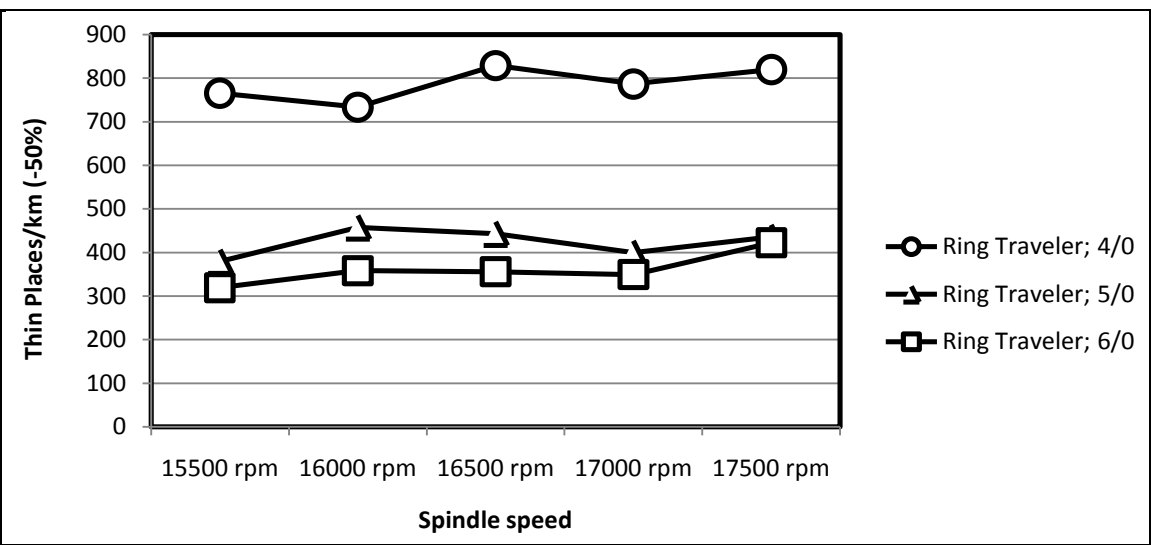

Figure 4. Thin places/km $(-50 \%)$ of Ne 34 Carded slub yarn with different ring spindle speed and ring traveller.

then thick places $/ \mathrm{km}(+50 \%)$ also increases but yarn thick places $/ \mathrm{km}(+50 \%)$ is requirement because it represents the no. of slub. So for Ne 28 and Ne 30 carded slub yarn traveller number $4 / 0$ is suitable. The number of thick places of $\mathrm{Ne} 30$ is more than Ne 28 carded slub yarn. In addition to the traveller number 5/0 and $6 / 0$ were shown approximately similar result and traveler number $4 / 0$ was given highest thick places per kilometer.

\subsection{Effect of Ring Spindle Speed and Traveller Number on Yarn Hairiness and End Breakage Rate}

From Table 5, it was observed that when spindle speed increase end breakage\% also increase and vice versa. In case of yarn count $\mathrm{Ne} 28$, the end breakage\% was shown $6.50,5.30$ and 7.90 with the traveller number of $3 / 0,4 / 0$ and $5 / 0$ respectively at $17,500 \mathrm{rpm}$. In addition to the end breakage\% was also shown $6.25,4.75$ and 7.6 with the traveller number of $3 / 0,4 / 0$ and $5 / 0$ respectively at $17,500 \mathrm{rpm}$ for yarn count $\mathrm{Ne} 30$. Above discussion it was clear that traveller number $4 / 0$ was given the best result as traveller number $4 / 0$ shown lower end breakage rate as compared to others.

Yarn hairiness is defined as the protrusion of fibres from the core of yarn structure [17].

Yarn hairiness influences the fabric appearance, handle, pilling tendency and yarn strength. Broadly spindle speed and traveler mass mostly influenced the yarn hairiness. From the Table 5, it was observed that higher spindle speed responsible for upper level of hairiness index at different traveller weight. This outcome bears the other authors [18]. Traveller number 5/0 shown slightly higher hairiness index than traveller $3 / 0$ and $4 / 0$. Among the traveller, 4/0 number is suitable for $\mathrm{Ne} 28$ and $\mathrm{Ne} 30$ carded slub as it was given lower hairiness index at highest spindle speed $17,000 \mathrm{rpm}$. It is very clear that hairiness index reduces with the increase in traveller mass $3 / 0$ to $4 / 0$ but slightly increases hairiness index for traveller 5/0. This result supported by number of author [19] [20]. A number of researcher have found that hairiness reduce with increase traveler 


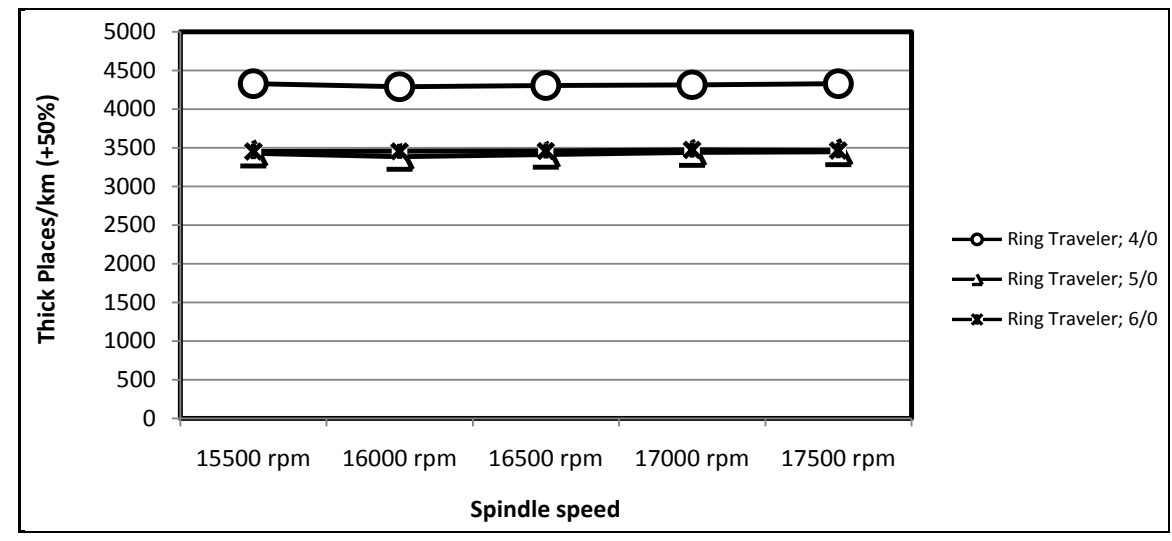

Figure 5. Comparison of thick places $/ \mathrm{km}(+50 \%)$ of Ne 34 Carded slub yarn with different ring spindle speed and ring traveler.

Table 5. Hairiness and end breakage $\%$ of $\mathrm{Ne} 28$ and $\mathrm{Ne} 30$ Carded slub yarn with different ring spindle speed and ring traveller.

\begin{tabular}{|c|c|c|c|c|c|}
\hline \multicolumn{6}{|c|}{ Yarn Count Ne $28 \mathrm{Ne} 30 \mathrm{Ne} 28 \mathrm{Ne} 30$} \\
\hline Traveller Number & Spindle Speed (rpm) & Hairiness Index & Hairiness Index & End Breakage\% & End Breakage\% \\
\hline \multirow{5}{*}{$3 / 0$} & 15,500 & 6.03 & 5.59 & 3.75 & 4.25 \\
\hline & 16,000 & 5.93 & 5.68 & 4.10 & 4.59 \\
\hline & 16,500 & 6.57 & 5.84 & 4.25 & 5.25 \\
\hline & 17,000 & 5.86 & 6.22 & 5.85 & 6.19 \\
\hline & 17,500 & 6.28 & 6.37 & 6.50 & 6.25 \\
\hline \multirow{5}{*}{$4 / 0$} & 15,500 & 6.09 & 6.03 & 4.04 & 3.75 \\
\hline & 16,000 & 5.89 & 5.97 & 4.24 & 4.1 \\
\hline & 16,500 & 5.86 & 5.65 & 4.70 & 4.2 \\
\hline & 17,000 & 5.88 & 5.75 & 5.10 & 4.4 \\
\hline & 17,500 & 6.18 & 5.89 & 5.30 & 4.75 \\
\hline \multirow{5}{*}{$5 / 0$} & 15,500 & 6.28 & 5.9 & 5.20 & 4.2 \\
\hline & 16,000 & 6.14 & 5.93 & 5.95 & 4.6 \\
\hline & 16,500 & 6.09 & 5.96 & 6.40 & 5.9 \\
\hline & 17,000 & 6.10 & 6.04 & 7.00 & 7.5 \\
\hline & 17,500 & 6.28 & 6.17 & 7.90 & 7.6 \\
\hline
\end{tabular}

mass. But the reduction is thought to be up to a certain traveler mass before it begins to increase again.

From the Figure 6, it was observed that traveller number $4 / 0$ showed lower hairiness index in all cases except 16,500 rpm than traveller number 5/0 and 6/0 for Ne 34 carded slub yarn. The hairiness index was sharply increase at 16,000 rpm and slight goes down at $16,500 \mathrm{rpm}$ but dramatically fall at 17,000 rpm and again rise at 17,500 rpm in case of traveller number 5/0. Again the hairiness index was gradually increase of traveller number $6 / 0$ in all spindle speed except $16500 \mathrm{rpm}$. It can be conclude that traveller number $4 / 0$ was given best result. 


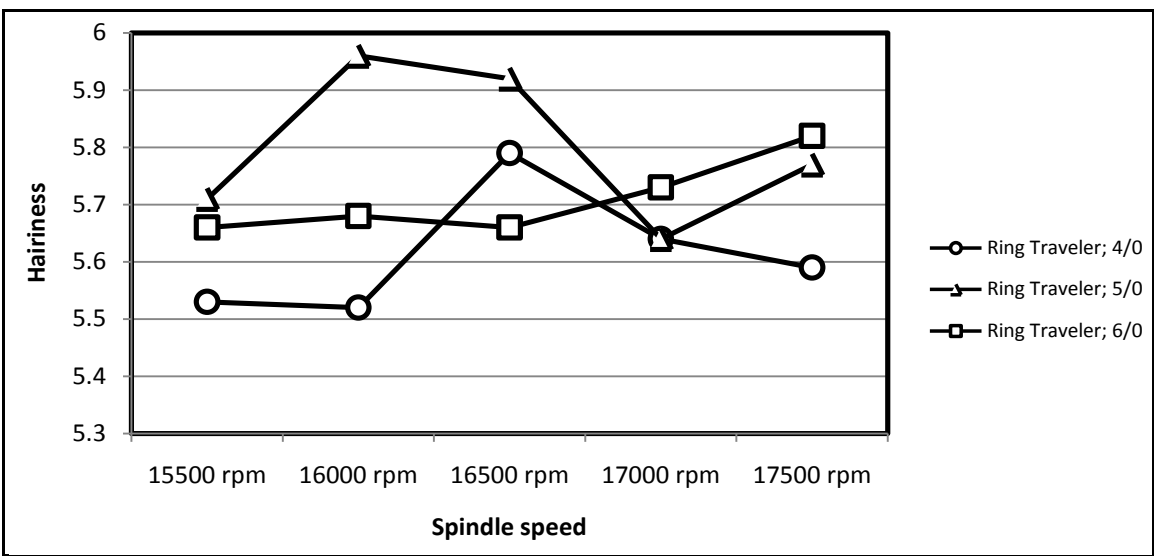

Figure 6. Comparison of hairiness of Ne 34 Carded slub yarn with different ring spindle speed and ring traveller.

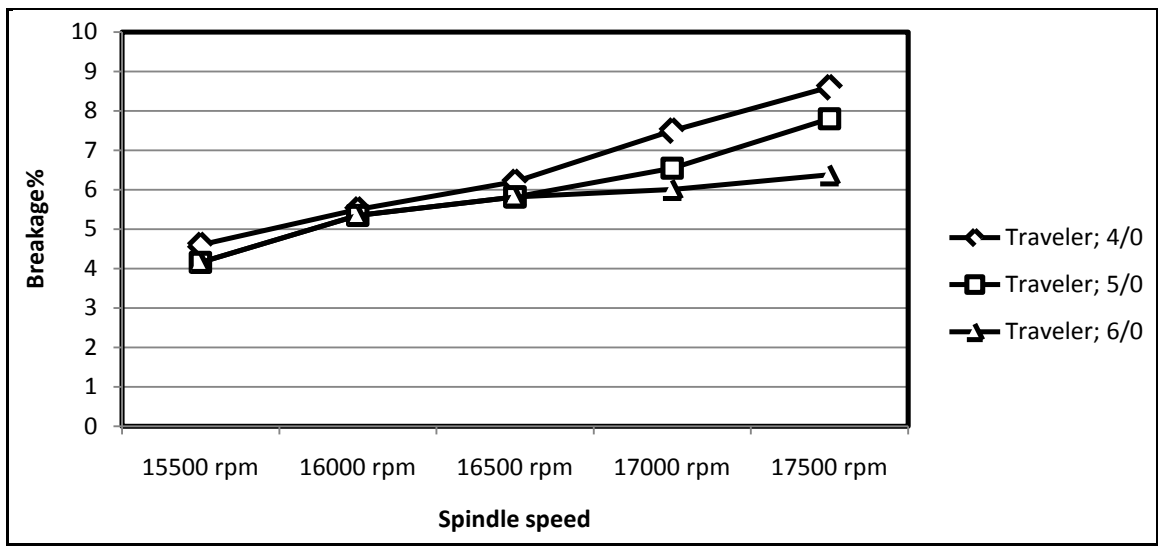

Figure 7. Comparison of End Breakage\% of Ne 34 Carded slub yarn with different ring spindle speed and ring traveller.

In the Figure 7 for Ne 34 carded slub yarn, it was found that the end breakage rate increases with the increase in spindle speed and vice versa. But traveller mass increases; the end breakage rate also decreases. On the other hand lighter weight travellers responsible for more yarn end breakage as a result machine efficiency and production will go down. Furthermore lighter weight travellers increase the traveller speed but it disturbs the winding speed. This disturbance happening more yarn breakage and also reduce the yarn quality [3]. The suitable traveller selection is the key to achieve optimum production. Among the traveller, traveller number $6 / 0$ is excellent for better production at $17500 \mathrm{rpm}$ of spindle speed for 34 carded slub yarn.

\section{Conclusion}

In this study $\mathrm{U} \%, \mathrm{CVm} \%$, thin places, thick places, hairiness index and end breakage\% have been observed by changing spindle speed and traveller number in ring frame. The traveler number $5 / 0$ showed better result in terms of $\mathrm{U} \%$, $\mathrm{CVm} \%$ at maximum spindle speed for Ne 28 and Ne 30 carded slub yarn. There 
is no significant difference for thin places per kilometer. On the other hand traveler number $4 / 0$ is given the highest thick places and the lowest end breakage\% and hairiness index. So traveler number $4 / 0$ is suitable for $\mathrm{Ne} 28$ and $\mathrm{Ne} 30$ carded slub yarn production. Again traveller number $6 / 0$ is given the best result in terms of $\mathrm{U} \%, \mathrm{CVm} \%$, thin places $/ \mathrm{km}$ and end breakage\% for Ne 34 carded slub yarn. On the other hand, traveler number $4 / 0$ showed the lowest hairiness index and the highest thick places per kilometer for Ne 34 cared slub yarn. So it can be said that traveler number $4 / 0$ is the best for slub yarn production purpose but $6 / 0$ is suitable for overall spinning performance.

\section{References}

[1] Kwasniak, J. (1997) Application of a Pressurized-Air Method of Fancy-Yarn Formation to Industrial Rotor-Spinning Machines. Journal of the Textile Institute, 88, 185-197. https://doi.org/10.1080/00405009708658544

[2] Amsler, B. and Olsson, P. (1991) Economic Benefits in Fancy Yarn. Textile Month, 31-35.

[3] Amsler, B. (2004) Fancy Yarn Opportunities in Spinning Process. International Textile Buletin, 2, 40-42.

[4] Spamth, V.R. (2004) Fancy Yarns in Open End Spinning. Asian Textile Journal, 13, 52-54.

[5] Product Review (2004) Amsler Equipment to Spin Fancy \& Elastic Yarn. Indian Textile Journal, 114, 37.

[6] Nemailal, T. (2002) Effect of Speed, Twist, Draft on Ring Spun Yarn. Indian Textile Journal, 11, 10,

[7] Barella, A. and Manich, A. ((2002) Yarn Hairiness: A Further Update. Textile Progress, 31, 1-44. https://doi.org/10.1080/00405160208688953

[8] Usta, I. and Canoglu, S. (2002) Influence of Ring Traveller Weight and Coating on Hairiness of Acrylic Yarns. Fibres and Textiles in Eastern Europe, 20-24.

[9] Merril, G.R. (1999) Manual of Textile. Universal Publication Corporation, Mumbai.

[10] Lord, P.R. (2003) Handbook of Production, Technology, Science and Economics. The Textile Institute, Woodhead Publishing Ltd., Cambridge, 71.

[11] Azzouz, B., Hassan, M.B. and Sakli, F. (2007) Quality Prediction and Optimizing Cotton Blend Using ANN. Indian Textile Journal, 1, 27-34.

[12] Lawal, A.S. (2008) Studies on the Effects of Some Spinning Parameters on Various Blends of Flax/Cotton Yarns Spun Using Ring and Rotor Spinning Techniques. Ph.D. Thesis. Ahmadu Bello University, Zaria.

[13] Grosberg, P. and Iype, C. (1999) Yarn Production, Theoretical Aspect. The Textile Institute, Manchester, 99-113.

[14] Nemailal, T. (2002) Effect of Speed, Twist, Draft on Ring Spun Yarn. Indian Textile Journal, 11, 19-28.

[15] Schlafhorst (1995) Preparation of Linen Fibres and Their Processing in Ring and Rotor Spinning. Manchenglabatch, 33.

[16] Gong, R.H. and Wright, R.M. (2002) Fancy Yarns: Their Manufacture and Application. Woodhead Publishing Limited, Cambridge, 60-91.

https://doi.org/10.1533/9781855737525.60 
[17] Wang, X. and Chang, L. (2003) Reducing Yarn Hairiness with a Modified Yam Path in Worsted Ring Spinning. Textile Research Journal, 73, 327-332. https://doi.org/10.1177/004051750307300409

[18] Wang, X. and Miao, M. (1997) Reducing Yarn Hairiness with an Air-Jet Attachment during Winding. Textile Research Journal, 67, 481-485. https://doi.org/10.1177/004051759706700702

[19] Pillay, K.P.R. (1964) A Study of the Hairiness of Cotton Yarns Part I: Effect of Fiber and Yarn Factors. Textile Research Journal, 34, 663-674. https://doi.org/10.1177/004051756403400802

[20] Tang, Z.-X., Wang, X., Wang, L. and Fraser, W.B. (2006) The Effect of Yarn Hairiness on Air Drag in Ring Spinning. Textile Research Journal, 76, 559-566. https://doi.org/10.1177/0040517506064472 